JURNAL ILMIAH KOMPUTERISASI AKUNTANSI, Vol. 13, No. 2, Desember 2020, pp.143-153

p-ISSN : 1979-116X (print)

e-ISSN : 2614-8870 (online)

http://journal.stekom.ac.id/index.php/kompak

\title{
Penerapan Management Information Systems Untuk Kelayakan Pinjaman Menggunakan Metode Fuzzy Logic Model Tsukamoto
}

\author{
Robby Andika Kusumajaya ${ }^{1}$, Dendy Kurniawan ${ }^{2}$, Haris Ihsanil Huda ${ }^{3}$, Eko Siswanto ${ }^{4}$ \\ ${ }^{1}$ Universitas Sains Dan Teknologi Komputer \\ e-mail: robby@stekom.ac.id \\ ${ }^{2}$ Universitas Sains Dan Teknologi Komputer \\ e-mail: dendy@stekom.ac.id \\ ${ }^{3}$ Universitas Sains Dan Teknologi Komputer \\ e-mail: haris@stekom.ac.id \\ ${ }^{4}$ Universitas Sains Dan Teknologi Komputer \\ e-mail: eko.siswanto@stekom.ac.id
}

\section{ARTICLE INFO}

Article history:

Received 19 Oktober 2020

Received in revised form 21 Oktober 2020

Accepted 25 Oktober 2020

Available online 01 Desember 2020

\begin{abstract}
KSP (Cooperative Saves and Borrow) Makmur Mandiri is engaged in a credit business that provides loans or credit as a cooperative in general. The loan acceptance system in the ongoing KSP Makmur Mandiri is carried out by way of prospective borrowers coming to the cooperative location by applying for a loan and then employees register the borrower into the member recommendation form after which the member recommendation form is given to the cooperative leadership.

The problem that occurs in KSP Makmur Mandiri is the presence of cooperative leaders who often do not exist in cooperatives, so that loan applications in cooperatives accumulate and cannot be immediately determined the results of loan eligibility. In addition, the problem that also occurs in cooperatives is the assessment made by the leadership in determining the feasibility of the loan is still subjective, namely only giving a decent decision or not a borrower, without taking into account the percentage of the value of the loan.

The solution to solve this problem is a decision to determine eligibility that is able to help the leadership in the assessment process and provide appropriate calculations in assessing the feasibility of the loan. The method that can support decisions is Fuzzy logic, because assessments that are subjective or non-linear can be modeled and calculated precisely.
\end{abstract}

Keywords: Management Information Systems, Fuzzy Logic Methods, KSP Makmur Mandiri. 


\section{Abstrak}

KSP (Koperasi Simpan Pinjam) Makmur Mandiri bergerak dalam usaha perkreditan yang menyediakan pinjaman atau kredit sebagai mana koperasi pada umumnya. Sistem penerimaan pinjaman dalam KSP Makmur Mandiri yang sedang berjalan dilakukan dengan cara calon peminjam datang ke lokasi koperasi dengan mengajukan peminjaman kemudian karyawan mendata peminjam ke dalam form rekomendasi anggota setelah itu form rekomendasi anggota tersebut diberikan kepada pimpinan koperasi.

Masalah yang terjadi pada KSP Makmur Mandiri adalah kehadiran pimpinan koperasi yang sering tidak ada di koperasi, sehingga pengajuan pinjaman yang ada di koperasi menumpuk dan tidak dapat segera di tentukan hasil kelayakan pinjaman. Selain itu masalah yang juga terjadi di koperasi adalah penilaian yang dilakukan pimpinan dalam menentukan kelayakan pinjaman masih bersifat subyektif yaitu hanya memberikan keputusan layak atau tidak seorang peminjam, tanpa memperhitungkan persentase nilai kelayakan pinjaman tersebut.

Solusi untuk menyelesaikan masalah ini maka dibuatlah sebuah keputusan penentuan kelayakan yang mampu membantu pimpinan dalam proses penilaian dan memberikan perhitungan tepat dalam menilai kelayakan pinjaman. Metode yang dapat mendukung keputusan adalah Fuzzy logic, karena penilain yang bersifat subyektif atau non-linear dapat dimodelkan dandihitung secara tepat.

Kata Kunci: Sistem Informasi Manajemen, Metode Fuzzy logic, KSP Makmur Mandiri.

\section{PENDAHULUAN}

Sistem informasi dan teknologi telah menjadi komponen yang sangat penting bagikeberhasilan bisnis dan organisasi. Teknologi informasi, termasuk sistem informasi berbasis internet memainkan peranan penting dan makin luas dalam bisnis. Teknologi informasi dapat membantu segala jenis bisnis meningkatkan efesiensi dan efektifitasproses bisnis mereka, pengambilan keputusan manajerial, dan kerja sama kelompokkerja, hingga dapat memperkuat posisi kompetitif mereka dalam pasar yang cepat sekali berubah. Hal ini berlaku ketika perkembangan teknnologi komputer yang semakin pesat pada zaman ini semakin banyak memberikan manfaat dalam kehidupan manusia, salah satu manfaatnya yaitu sebagai sistem yang dapat membantu manusia dalam mengambil keputusan untuk menyelesaikan masalah sehari-hari. Salah satu contoh dari masalahsehari - hari tersebut yaitu menentukan kelayakan peminjaman di suatu koperasi, sehingga dibutuhkan suatu sistem yang dapat menyelesaikan masalah tersebut.

Koperasi menurut Undang-Undang Nomor 25 tahun 1992 adalah "badan usaha yang beranggotakan orang, seorang atau badan hukum koperasi dengan melandaskan prinsip -prinsip koperasi sekaligus sebagai gerakan ekonomi rakyat yang berdasarkan atas asas kekeluargaan" [1]. Dari dasar tersebut, dapat diketahui bahwa koperasi mengandung dua unsur, yaitu unsur ekonomi dan unsur social yang berkaitan satu sama lain. Dikatakan memiliki unsur ekonomi karena tujuan dari koperasi itu sendiri adalah untuk mencapai kesejahteraan anggota, sedangkan unsur sosial terlihat dari adanya asas yang dijunjung dalam koperasi, yakni asas kekeluargaan.

KSP Makmur Mandiri merupakan koperasi simpan pinjam yang bertujuan untuk memberikan jasa penyimpanan dan peminjaman modal usaha bagi karyawan kantor ataupun karyawan pabrik. Namun masalah yang terjadi pada koperasi selama ini adalah kehadiran pemilik yang sering tidak ada ditempat. Sehingga pengajuan pinjaman yangada di koperasi menumpuk dan tidak dapat segera direalisasi oleh pemilik. Hal inimengakibatkan keuntungan koperasi juga tidak dapat maksimal. Selain itu masalah yang juga terjadi dikoperasi adalah penilaian yang dilakukan pemilik dalam merealisasikan pinjaman masih bersifat subyektif yaitu hanya memberikan keputusan layak atau tidak seorang nasabah diberikan pinjaman modal, tanpa memperhitungkan persentase nilai kelayakan pinjaman tersebut. Penilaian yang bersifat subyektif tersebut juga dikarenakan kesulitan pemilik dalam menghitung persentase kelayakan pinjaman.

Salah satu cara yang dapat digunakan dalam menentukan kelayakan pemberian kredit adalah dengan menerapkan logika fuzzy. Dipilihnya logika fuzzy karena dibandingkan dengan logika yang lain, logika fuzzy dapat menghasilkan keputusan yang lebih adil [2] . Selain itu, logika fuzzy juga mudah untuk dipahami, dapat memodelkan fungsinonlinear yang kompleks, mempunyai toleransi terhadap data yang kurang tepat, dapat membangun dan menerapkan pengalaman - pengalaman dari beberapa pakar secaralangsung tanpa harus melalui proses training, serta dapat bekerjasama dengan teknik - teknik kendali secara konvensional yang berdasarkan pada bahasa alami. Di dalam penerapan logika fuzzy terdapat beberapa metode, dan di setiap metode memiliki cara dan hasil perhitungan yang berbeda. Metode Tsukamoto dan metode Mamdani dalam perhitungannya mempunyai cara yang berbeda pada mesin inferensi dan defuzzyfikasi. Adapun metode yang diterapkan adalah metode Tsukamoto.

JURNAL ILMIAH KOMPUTERISASI AKUNTANSI, Vol.13, No.2, Desember 2020, pp.143-153 
Dari permasalahan yang terjadi pada KSP Makmur Mandiri Kendal yang telah disebutkan diatas, maka perlu dirancang sistem yang terkomputerisasi untuk melakukan seleksi calon peminjam baru dengan sistem seleksi kelayakan pinjaman yang mempunyaikualitas sesuai kriteria yang diberikan. Pengambilan keputusan dalam penerapan sistem informasi manajemen penentuan kelayakan pinjaman dengan menggunakan metode Metode Fuzzy Logic Model Tsukamoto, hal ini didasarkan keunggulan dari segi pengambilan keputusannya yang mudah dan sederhana.

\section{TINJAUAN PUSTAKA}

\subsection{Definisi Sistem}

Sistem adalah bagian- bagian elemen yang saling terkait atau terpadu yang dimaksudkan untuk mencapai suatu tujuan[3]. Sistem juga memiliki karakteristik sebagai berikut : Komponen sistem, Batasan sistem, Lingkungan luar sistem, Penghubung sistem, masukan sistem, keluaran sistem, dan sasaran system[4].

\subsection{Informasi}

Informasi merupakan hasil dari pengolahan data, akan tetapi tidak semua hasil daripengolahan tersebut bisa menjadi informasi, hasil pengolahan data yang tidak memberikan makna atau arti serta tidak bermanfaat bagi seseorang bukanlah merupakan informasi bagi orang tersebut [4].

\subsection{Klasfikasi Keputusan}

Keputusan diklasifikasi menjadi tiga [5] yaitu :

a. Keputusan terstruktur, keputusan terstruktur melihat situasi dimana prosuder yang diikuti ketika keputusan diperlukan, dapat disebutkan lebih awal.

b. Keputusan tak terstruktur, Keputusan tak terstruktur melibatkan situasi keputusan dimana tidak mungkinmenentukan lebih awal mengenai prosedur keputusan yang harus diikuti.

c. Keputusan semi terstruktur, Beberapa prosedur keputusan dapat ditentukan, namun tidak cukup untukmengarah ke suatu keputusan yang di rekomendasi.

\subsection{Sistem informasi Manajemen (SIM)}

Sistem informasi manajemen adalah suatu sistem informasi yang selain melakukan pengolahan transaksi juga secara umum dapat dikatakan sebagai rangkaian kegiatan mulai dari pengumpulan, pengolahan, penyimpanan data sampai pada penyajian informasi bagi manajemen yang digunakan sebagai dasar pengambilan keputusan dalam rangka pencapaian tujuan [6].

\subsection{Metode Fuzzy}

Logika fuzzy pertama di kenalkan oleh Prof. Lotfi A. Zadeh pada tahun 1965. Logika fuzzy merupakan suatu metode pengambilan keputusan berbasis aturan yang digunakan untuk memecahkan keabu-abuan masalah pada sistem yang sulit dimodelkan atau memiliki ambiguitas[7].

Soft computing merupakan inovasi baru membangun sistem cerdas. Sistem cerdas ini merupakan sistem yang memiliki keahlian seperti manusia pada domain tertentu, mampu beradaptasi dan belajar agar dapat bekerja lebih baik jika terjadi perubahan lingkungan. Unsur - unsur pokok dalam Soft computing adalah: sistem fuzzy, jaringan saraf tiruan, probabilistic reasoning, evolutionary computing.

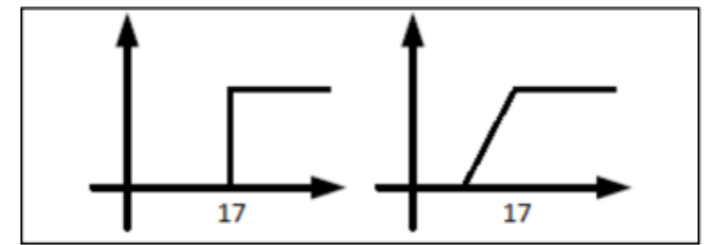

Gambar 1. Logika tegas (kiri) dan logika fuzzy (kanan) Sumber: (Kusumadewi, S. 2010)

\subsection{Metode Fuzzy Tsukamoto}


Pada metode Tsukamoto, setiap aturan direpresentasikan menggunakan himpunan -himpunan fuzzy, dengan fungsi keanggotaan yang monoton. Untuk menentukan nilai output crisp/hasil yang tegas (Z) dicari dengan cara mengubah input(berupa himpunan fuzzy yang diperoleh dari komposisi aturan - aturan fuzzy) menjadi suatu bilangan pada domain himpunan fuzzy tersebut. Cara ini disebut dengan metode defuzzifikasi(penegasan). Metode defuzzifikasi yang digunakan dalam metodetsukamoto adalah metode defuzzifikasi rata - rata terpusat (Center Average Defuzzyfier).[8]

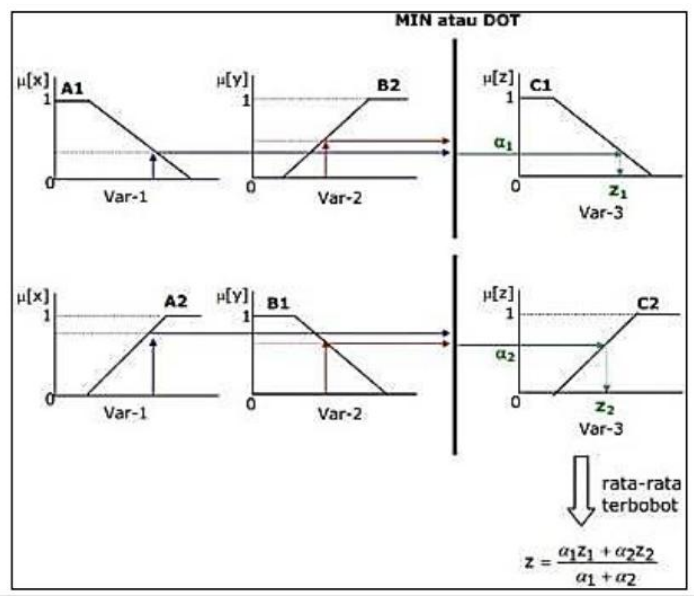

Gambar 2. Inferensi dengan menggunakan Metode Tsukamoto

Sumber : (Kusumadewi, S. 2010)

\section{METODOLOGI PENELITIAN}

\subsection{Metode Pengembangan}

Dalam pendekatan ini penulis menggunakan metode R \& D (Research and Development) adalah metode penelitian yang digunakan untuk menghasilkan produk tertentu, dan menguji keefektifan produk tersebut. Penelitian dan pengembangan (Research and Development) pada industri merupakan ujung tombak dari suatu industry dalam menghasilkan produk - produk baru yang dibutuhkan oleh pasar.[10]

\subsection{Flow Of Document}

3.2.1. Flow of Document Proses Kredit Nasabah Yang Sedang Berjalan

Tabel 1. Proses sistem yang berjalan

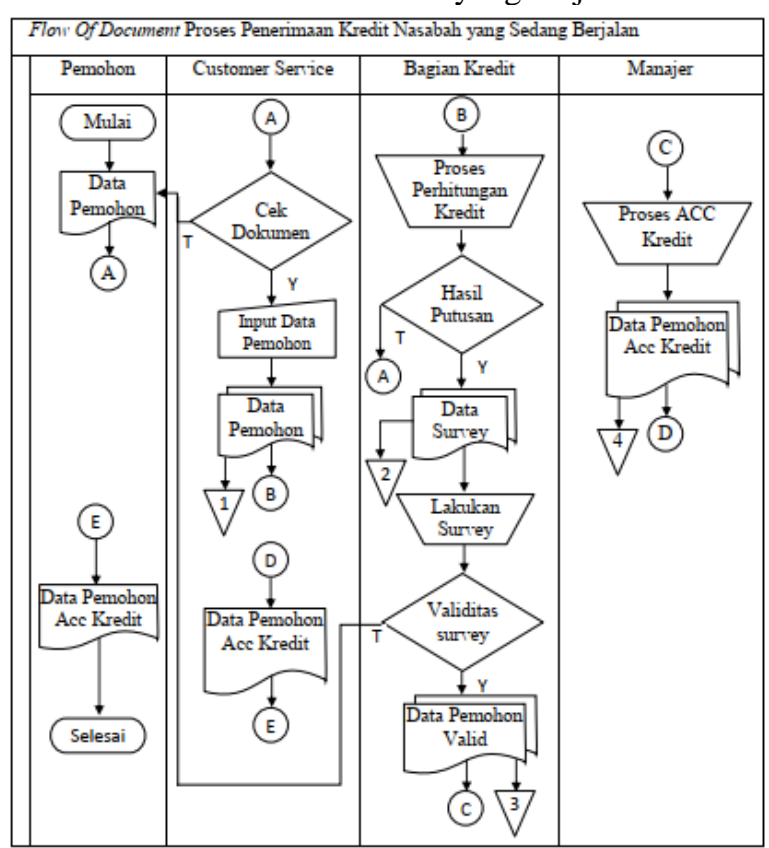

JURNAL ILMIAH KOMPUTERISASI AKUNTANSI, Vol.13, No.2, Desember 2020, pp.143-153 
3.2.2. Flow of Document Proses Kredit Yang Diusulkan

Tabel 2. Usulan Sistem Proses Kredit

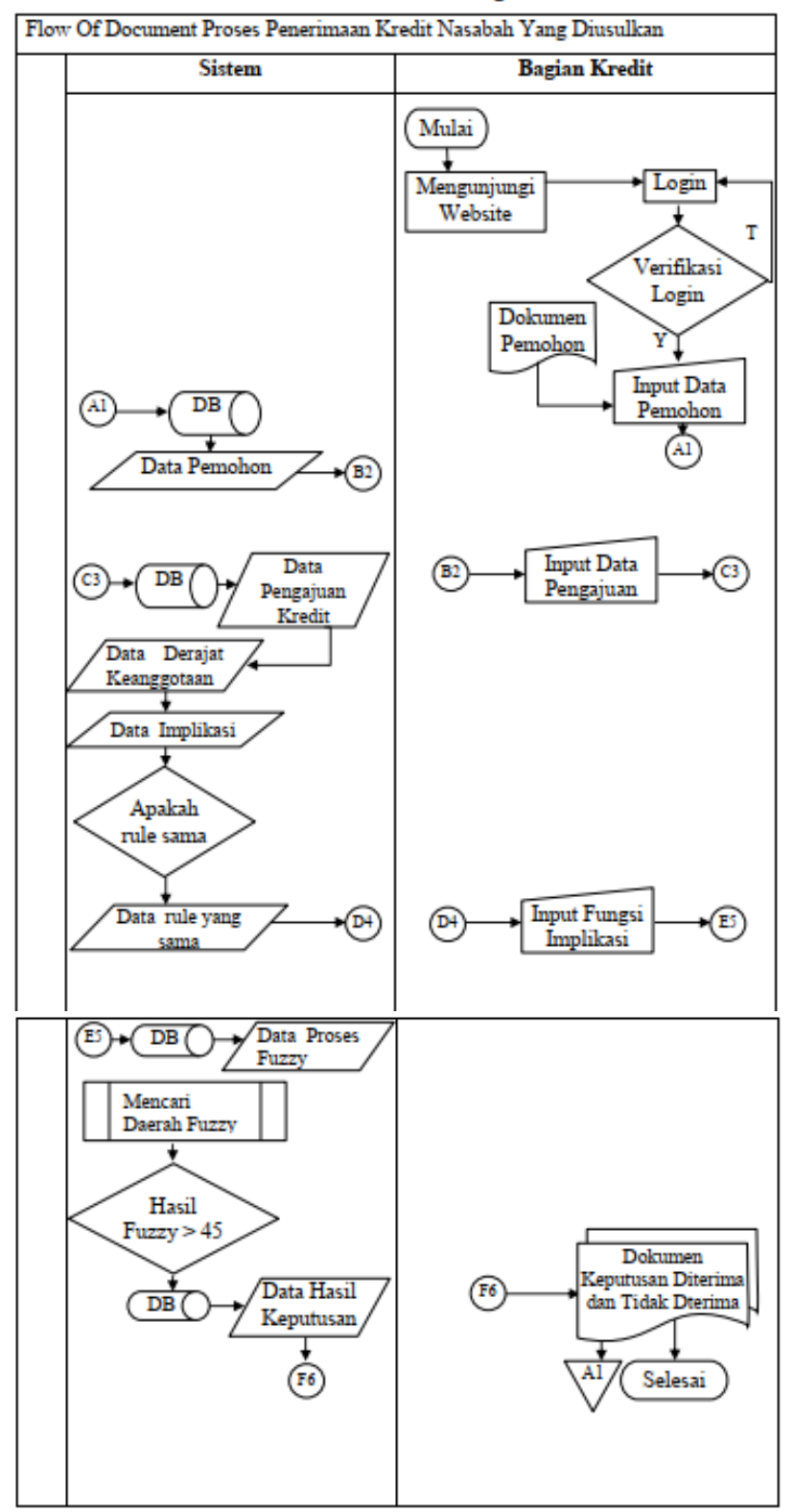

\subsection{Entity Relationship Diagram (ERD}




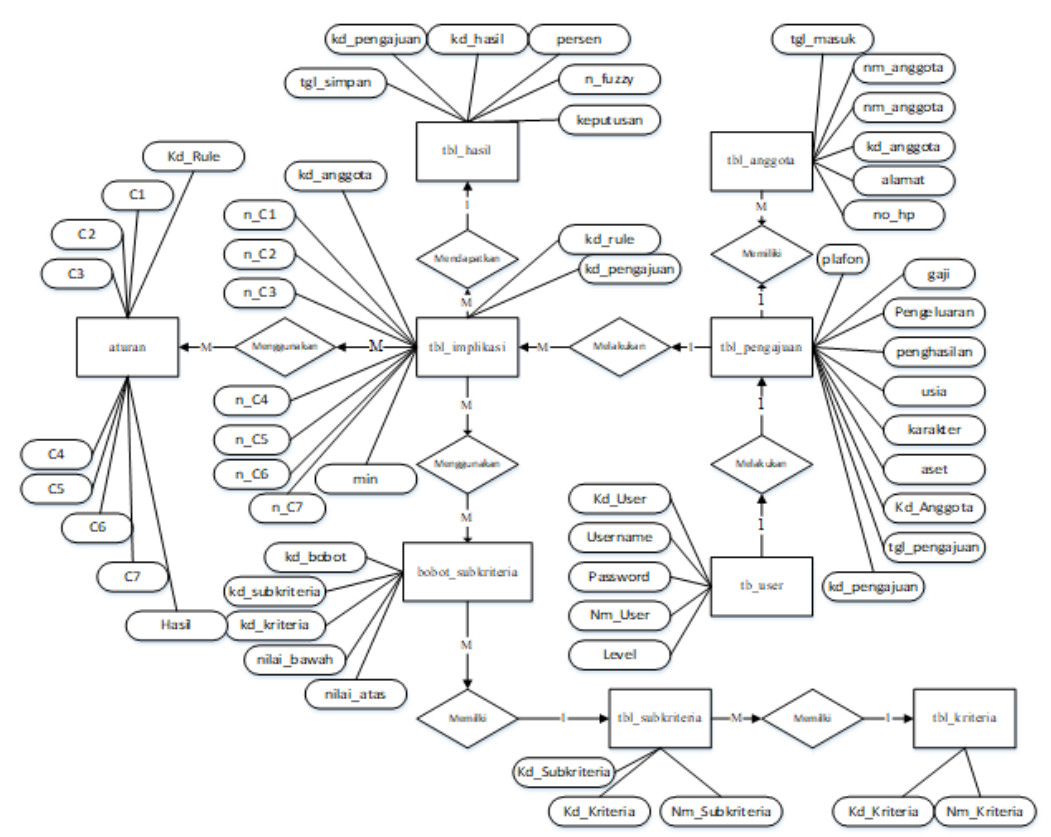

Gambar 3. ERD Sistem Usulan

\section{HASIL DAN PEMBAHASAN}

4.1. Hasil Penelitian

Hasil penelitian dari kinerja sistem kerja berdasarkan data dari 3 responden, nilai yang diperoleh :

Tabel 3. Hasil Kuesioner

\begin{tabular}{|c|c|c|c|c|c|}
\hline \multirow{2}{*}{ Responden } & \multicolumn{4}{|c|}{ Skor Untuk Butir Nomor } & \multirow{2}{*}{ Jumlah } \\
\cline { 2 - 5 } & $\mathrm{A}$ & $\mathrm{B}$ & $\mathrm{C}$ & $\mathrm{D}$ & \\
\hline User 1 & 3 & 4 & 4 & 3 & 14 \\
\hline User 2 & 4 & 4 & 3 & 4 & 15 \\
\hline User 3 & 3 & 4 & 3 & 4 & 14 \\
\hline Jumlah & 10 & 12 & 10 & 11 & 43 \\
\hline
\end{tabular}

Berdasarkan tabel diatas diperoleh jumlah data adalah 43. Dengan demikian, efektivitas sistem kerja adalah $43: 48=0,89$ atau 89,0\% dari kriteria yang diharapkan.Jika dilihat kinerja sistem berdasarkan ketepatan penyelesaian sebesar $10: 12=0,83$ atau $83 \%$ dari kriteria yang diharapkan. Berdasarkan kemudahan mengakses informasisebesar $12: 12=1$ atau 100\% dari kinerja yang diharapkan. Berdasarkan kecepatan kinerja sebesar $10: 12=0,83$ atau 83\% dari kinerja yang diharapkan. Berdasarkan kemudahan kinerja sebesar $11: 12=0,92$ atau $92 \%$ dari kriteria yang diharapkan. Darihasil diatas dapat disimpulkan bahwa efektivitas sistem kerja baik karena rata - rata nilai yang diperoleh sebesar $89,5 \%$ dilihat dari beberapa aspek diatas.

4.2. Hasil Pengembangan Sistem

4.2.1. Halaman Login Administrator

JURNAL ILMIAH KOMPUTERISASI AKUNTANSI, Vol.13, No.2, Desember 2020, pp.143-153 


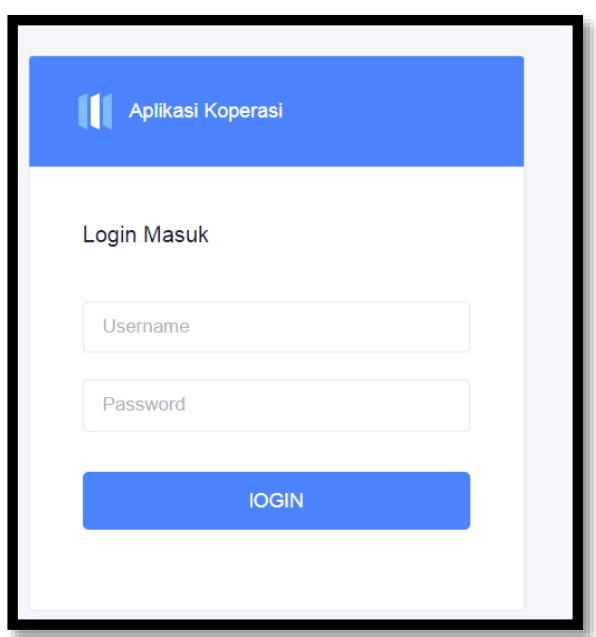

Gambar 4. Tampilan Login Sistem

4.2.2. Halaman Menu Utama Administrator

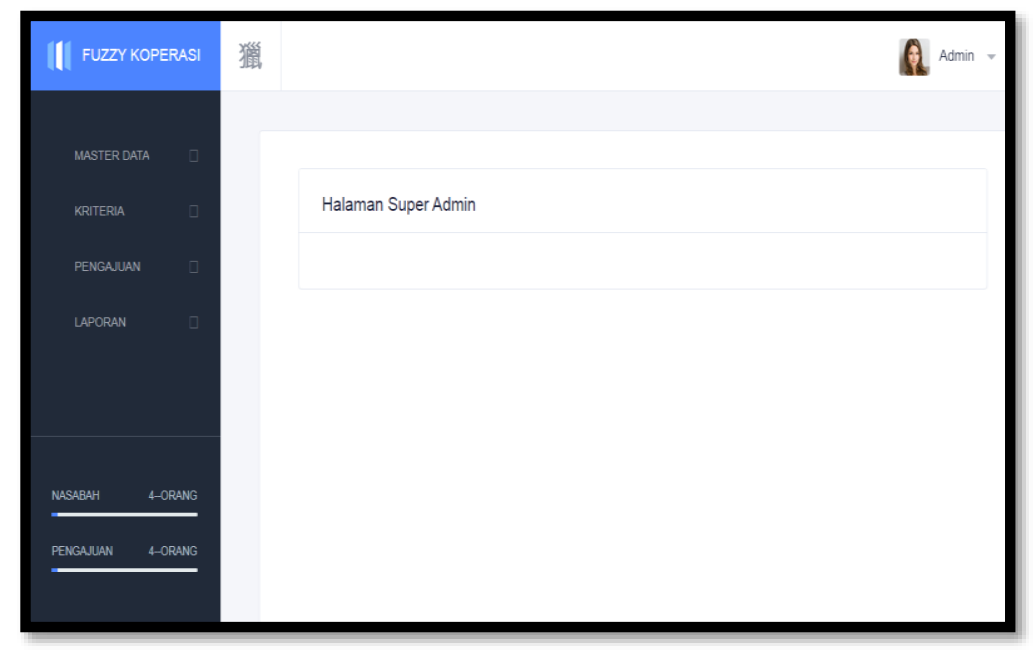

Gambar 5. Menu Utama Administrator Sistem

4.2.3. Halaman Menu Admin

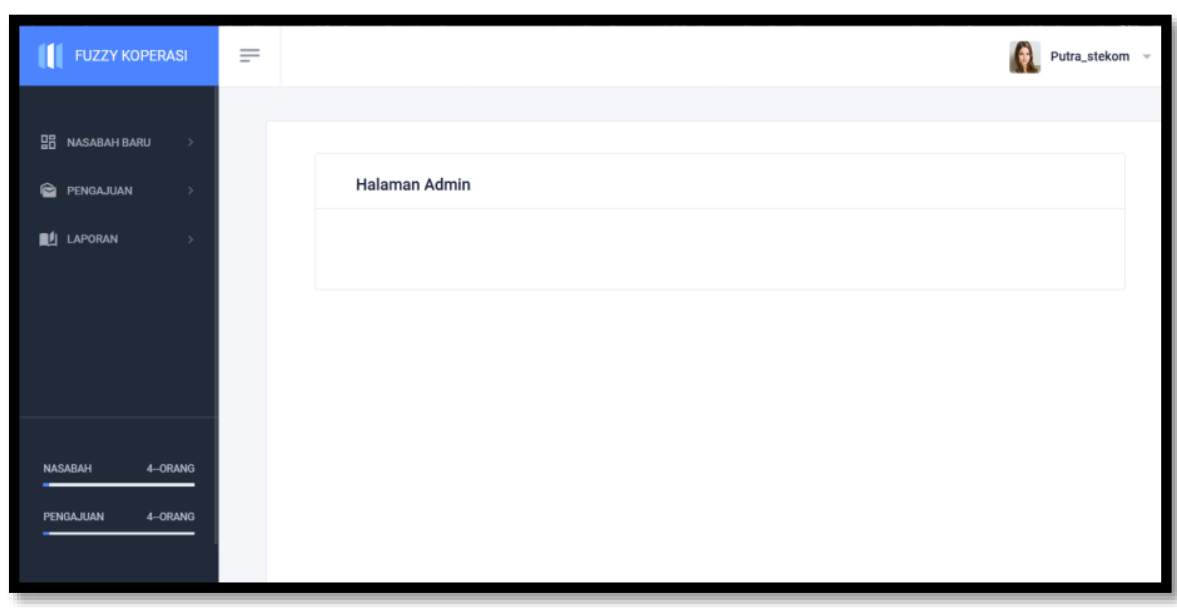

Penerapan Management Information Systems Untuk Kelayakan Pinjaman Menggunakan Metode Fuzzy Logic Model Tsukamoto (Robby Andika Kusumajaya, et al) 
Gambar 6. Menu Admin

4.2.4. Halaman Menu Manajer

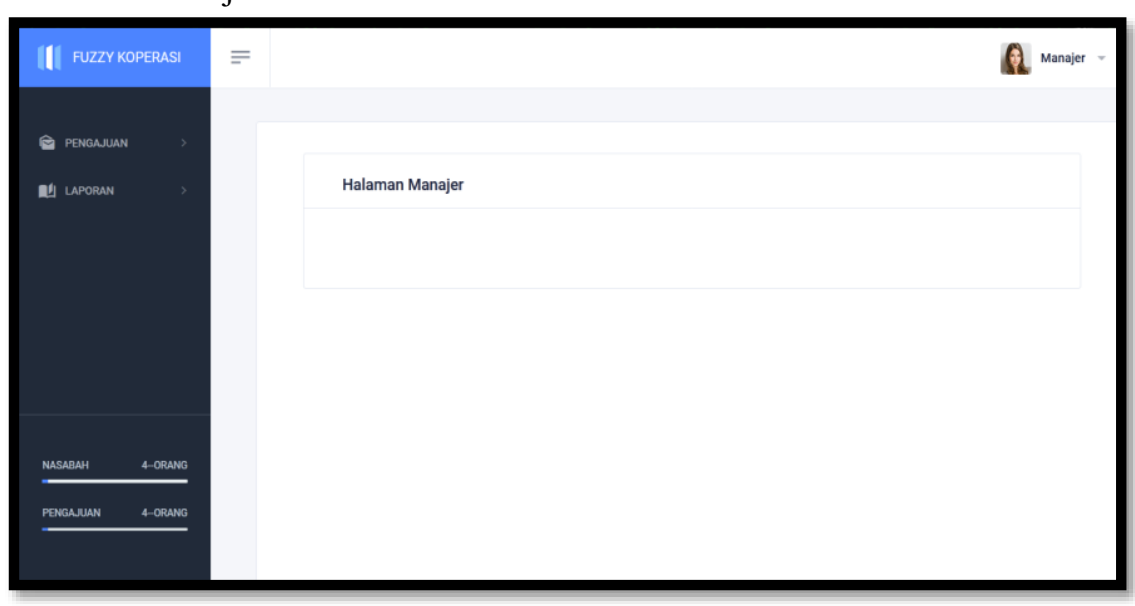

Gambar 7. Menu Manajer

4.2.5. Form Data Anggota

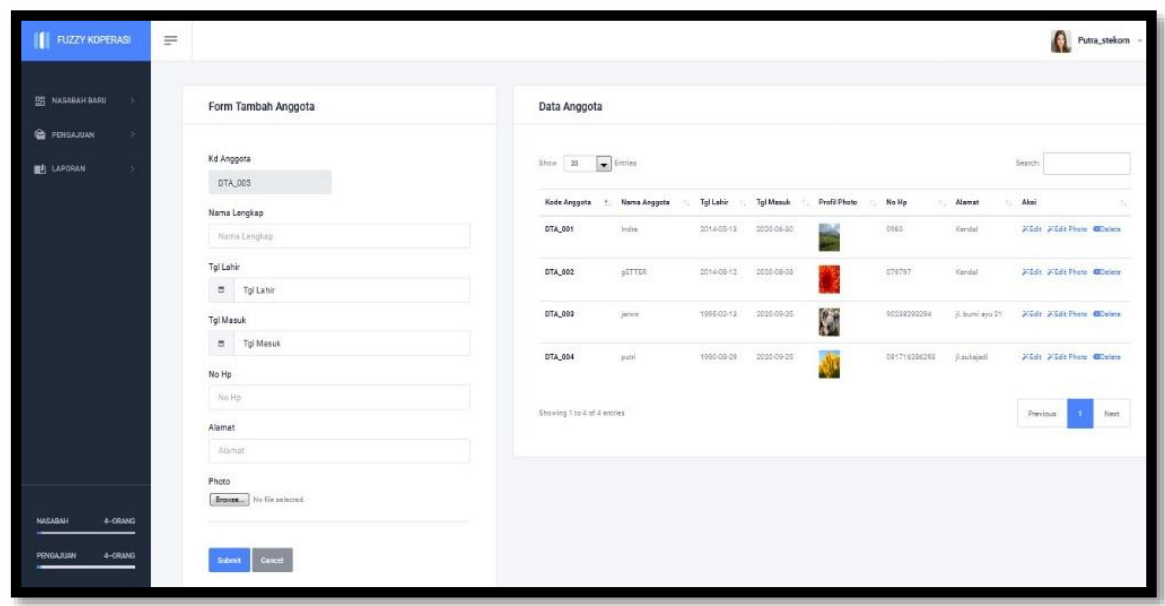

Gambar 8. Form Data Anggota

4.2.6. Form Pengajuan

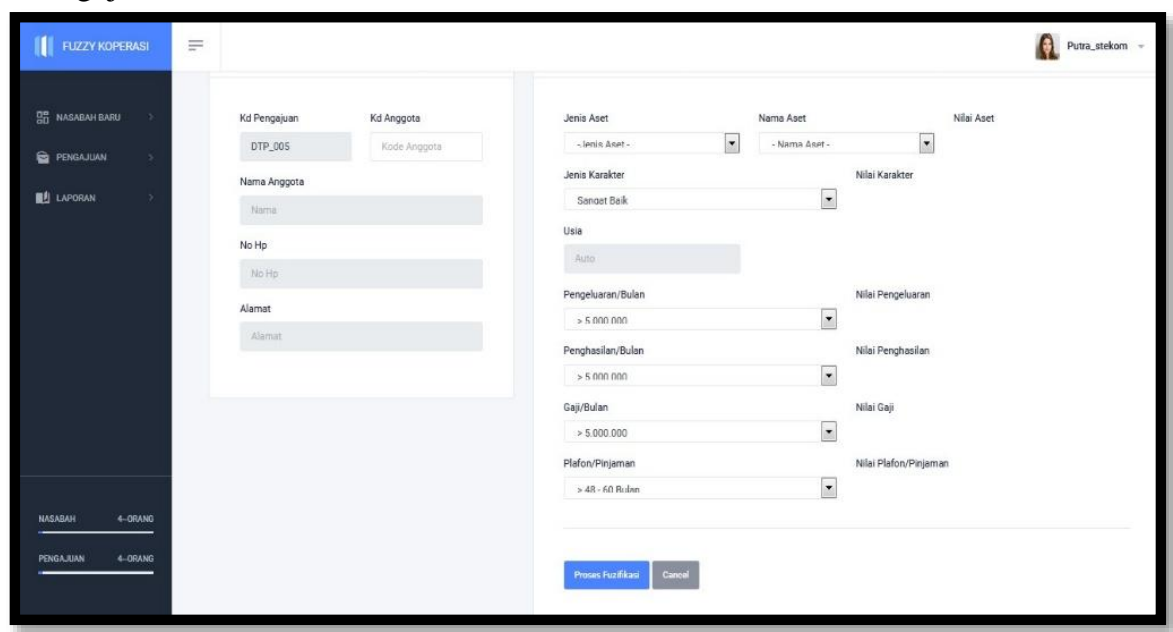

Gambar 9. Form Pengajuan

JURNAL ILMIAH KOMPUTERISASI AKUNTANSI, Vol.13, No.2, Desember 2020, pp.143-153 


\subsubsection{Form Kriteria}

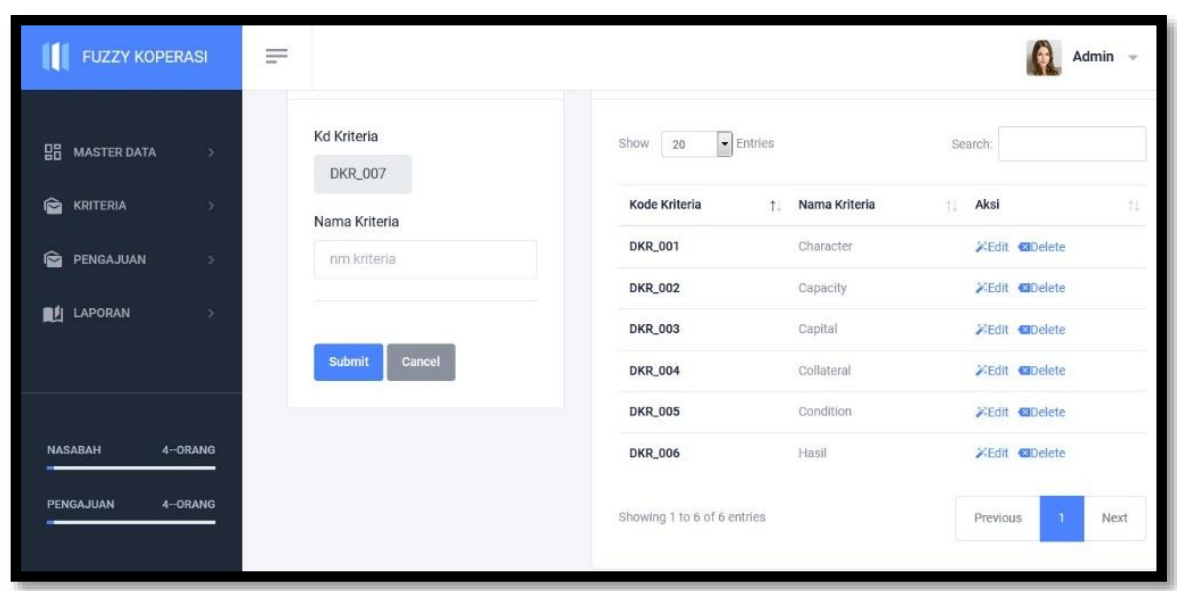

Gambar 10. Form Kriteria

4.2.8. Form Petugas dan Hak Akses

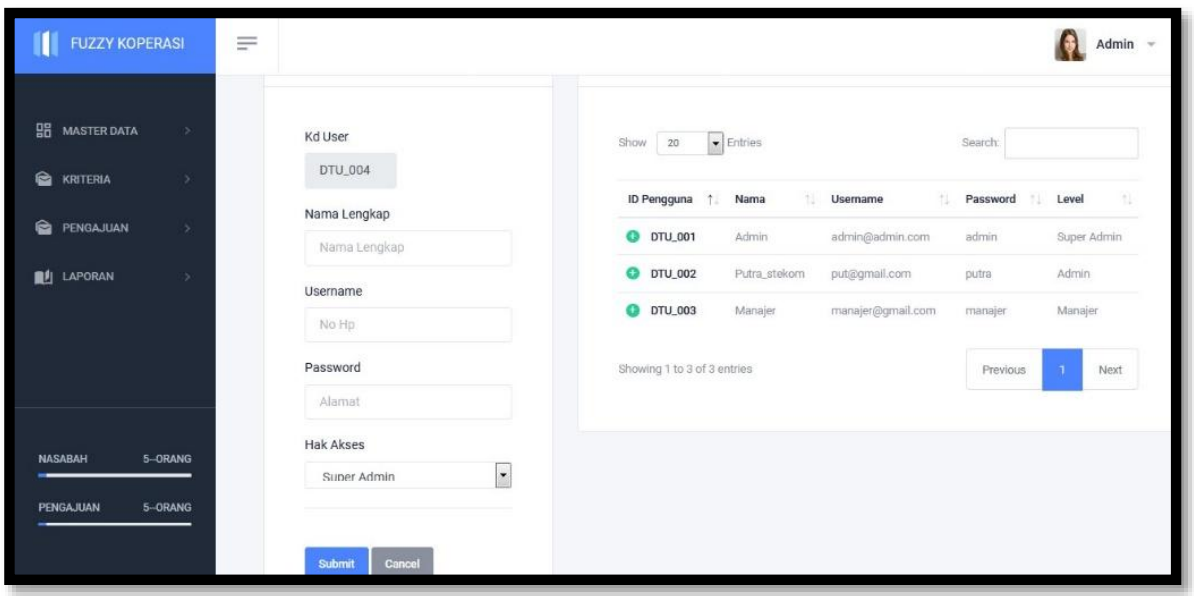

Gambar 11. Form Petugas dan Hak Akses

4.2.9. Laporan Data Anggota

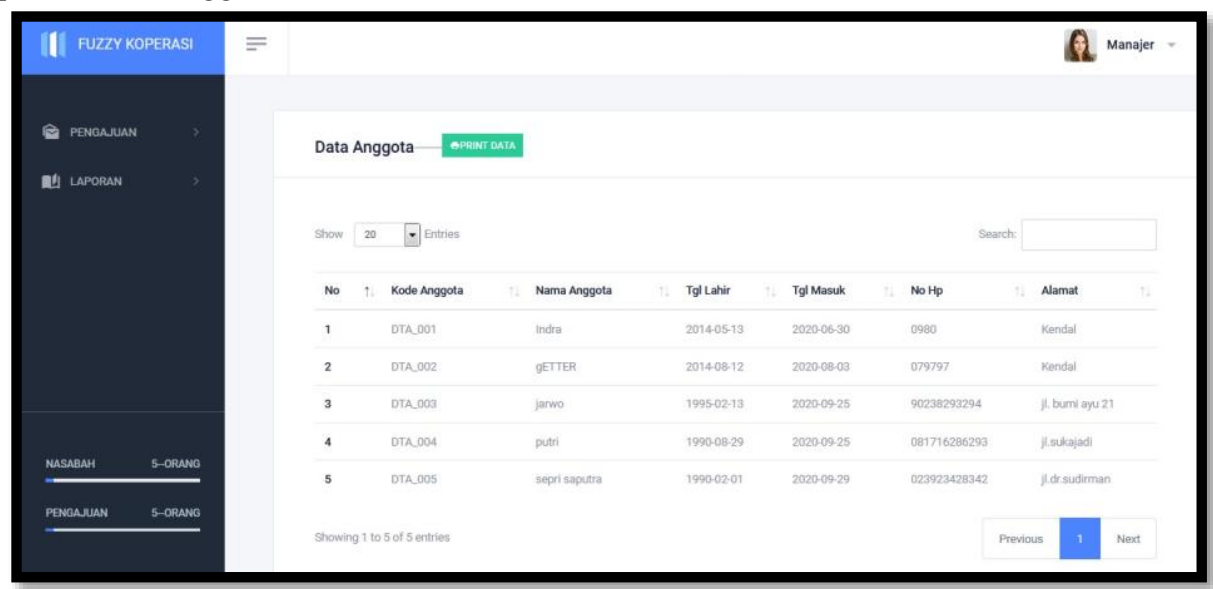

Gambar 12. Laporan Data Anggota

4.2.10. Laporan Data Hasil Keputuasan Diterima

Penerapan Management Information Systems Untuk Kelayakan Pinjaman Menggunakan Metode Fuzzy Logic Model Tsukamoto (Robby Andika Kusumajaya, et al) 


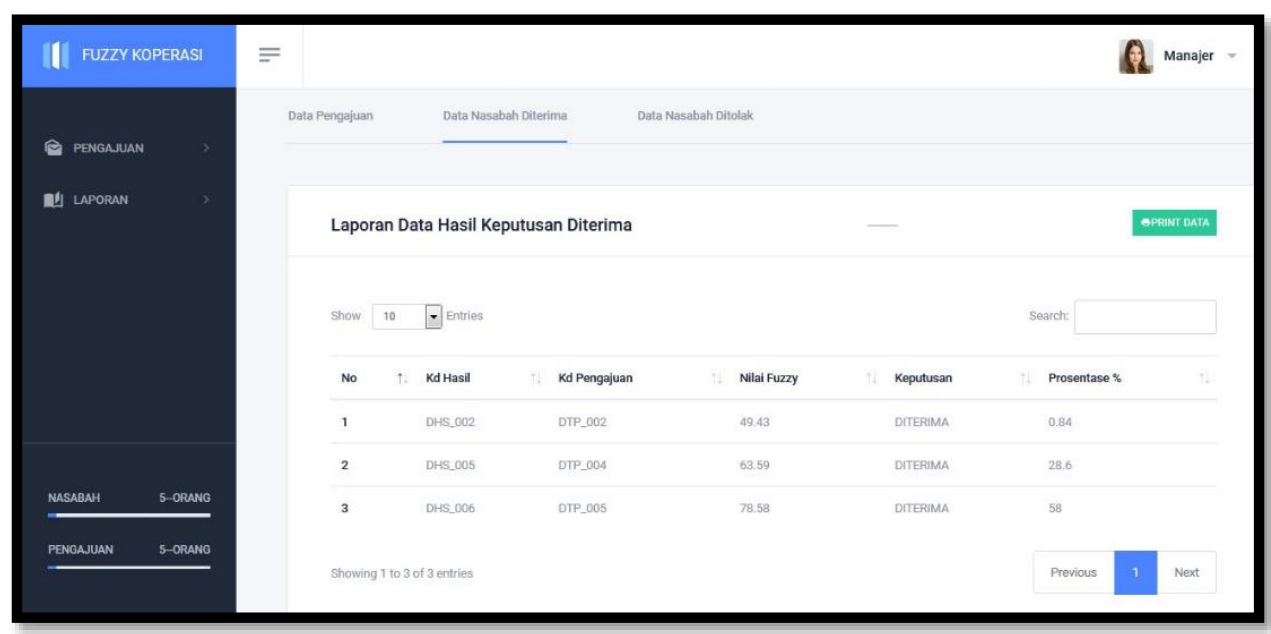

Gambar 13. Laporan Data Hasil Keputusan Diterima

4.2.11.Laporan Data Hasil Keputusan Ditolak

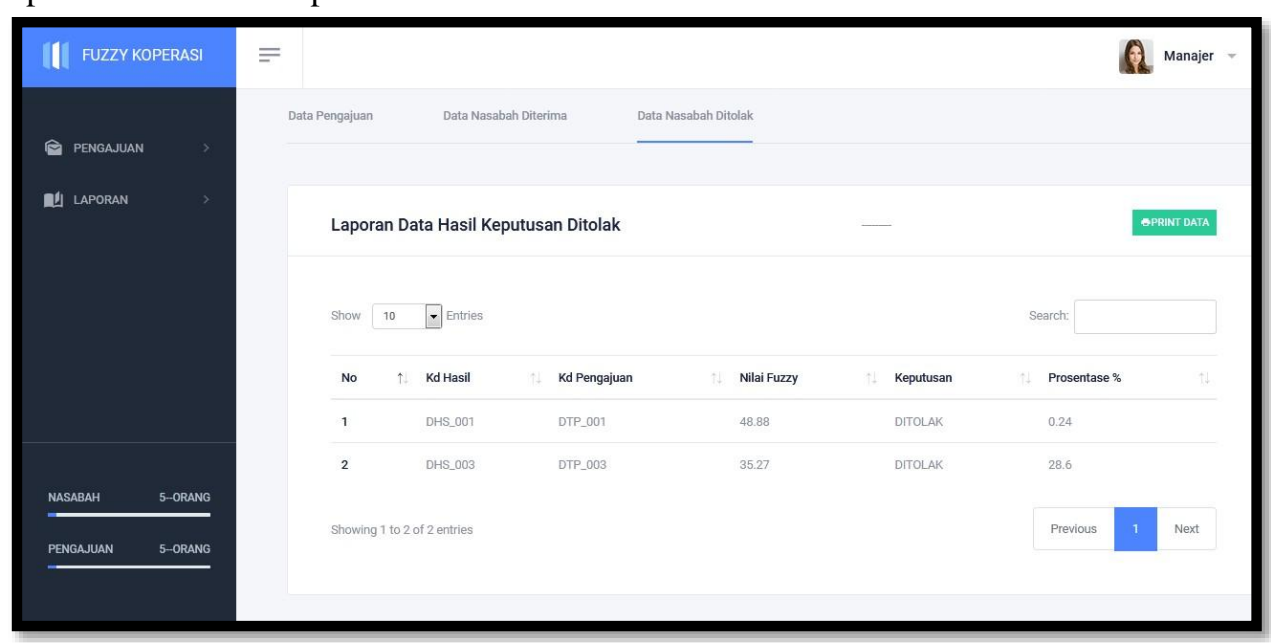

Gambar 14. Laporan Data Hasil Keputusan Ditolak

\section{Kesimpulan Dan Saran}

\subsection{Kesimpulan}

Setelah melalui tahap pengujian dan implementasi pada system ini maka kesimpulan yang diambil adalah : Sistem yang dibuat dapat membantu pemilik dalam menentukan kelayakan pinjaman nasabah sehingga memudahkan dalam mengambil keputusan penentuan pinjamannya. Sistem dapat menghasilkan nilai persentase kelayakan pinjaman nasabah, sehingga nilai tersebut lebih akurat. Sistem dapat menghasilkan keputusan kelayakan pinjaman per nasabah sehingga memudahkan pemilik menilai pengajuan pinjaman. Sistem dapat menentukan prioritas pemberian pinjaman nasabah yang dianggap layak sehingga modal koperasi dapat dicairkan kepada nasabah yang tepat. Beberapa rule base sistem belum sepenuhnya bisa menangani pengajuan pinjaman nasabah sehingga nilai persentase dan keputusan kelayakan pinjamannya kurang sesuai dengan output yang diharapkan.

\subsection{Saran}

Adapun saran yang dapat diberikan pada penelitian ini adalah, Kedepannya sistem ini dapat dikembangkan dalam bentuk mobile application berbasis android ataupun windows mobile sehingga dapat mengakses sistem inidimanapun dan kapanpun melalui handphonenya. Tujuannya adalah untuk memudahkan pengambilan keputusan tanpa harus berada di koperasi secara langsung atau saat berada di luar Koperasi. Peningkatan pada sisi keamanan sistem, meliputi authentication user privilleges supaya terhindar dari penggunaan hak ases

JURNAL ILMIAH KOMPUTERISASI AKUNTANSI, Vol.13, No.2, Desember 2020, pp.143-153 
pihak yang tidak bertanggung jawab dan terhindar dari hilangnya data akibat kesalahan akses tersebut. Penambahan rule base sistem supaya bisa menangani semua pengajuanpinjaman nasabah

\section{Daftar Pustaka}

[1] Undang-Undang Nomor 25 Tahun 1992 Tentang Perkoperasian

[2] Antony, P., Soewito, B., Ng, L.Y., and Ng, C.Y., 2017. Tsukamoto fuzzy implementation to identify the pond water quality of koi Tsukamoto fuzzy implementation to identify the pond water quality of koi. IOP Conference Series: Materials Science and Engineering PAPER, 0-7

[3] Abdul Kadir. 2018. Pemrograman Android \& Database (Diterbitka). Jakarta: Penerbit PT Elex Media Komputindo Kelompok Gramedia, Anggota IKAPI, Jakarta 2018.

[4] RA Kusumajaya, I Sembiring, A Iriani, 2019, “Analisis Kesiapan Tata Kelola Dan Investasisistem Informasi”. Smart Comp: Jurnalnya Orang Pintar Komputer, 2019

[5] Abdulhak, Ishak dan Darmawan. Deni. 2016. Pengembangan E-Learning Teori dan Desain. Bandung: PT Remaja Rosdakarya.

[6] Maulidiawati, Wida Tri. 2016. "Pengaruh Kelompok Acuan Terhadap Keputusan Pembelian pada Restoran Bersertifikat Halal MUI dengan Label Halal Sebagai Variabel Moderating (Study pada Mahasiswa Universitas Brawijaya Malang)". Jurnal Ilmiah, 2 (3): 1-10.

[7] Bahagia, S. 2017. Penggunaan Sistem Informasi Manajemen dalam Peningkatan Kompetensi Profesional Guru di MTsS Luqman Al-Haqim Kecamatan Lhoknga Aceh Besar. Banda Aceh: UIN ArRaniry.

[8] Dwisaputra, I., Rolastin, B., Irwan, I., \& Sateria, A. 2019. Pengambilan Keputusan Untuk Kualitas Air Pada Tambak Udang Menggunakan Fuzzy Logic Control. Jurnal Teknik Elektro, 2.

[9] Affifah, Dwi Yuni Nur., 2016. Optimalisasi Jumlah Produksi Jamu Jaya Asli dengan Metode Fuzzy Tsukamoto. Skripsi Sarjana Komputer, Universitas Nusantara Kediri.

[10] Borg, W. R. and M. D. Gall. 1989. Educational Research: An Introduction. Fifth Edition. New York and London: Longman 